Article

\title{
Chalinulasterol, a Chlorinated Steroid Disulfate from the Caribbean Sponge Chalinula molitba. Evaluation of Its Role as PXR Receptor Modulator
}

\section{Roberta Teta ${ }^{1}$, Gerardo Della Sala ${ }^{1}$, Barbara Renga ${ }^{2}$, Alfonso Mangoni ${ }^{1}$, Stefano Fiorucci ${ }^{2}$ and Valeria Costantino ${ }^{1, *}$}

1 The NeaNat Group, Department of Chemistry of Natural Products, University of Naples Federico II, Via D. Montesano 49, 80131 Napoli, Italy; E-Mails: roberta.teta@unina.it (R.T.); gerardo.dellasala@unina.it(G.D.S.); alfonso.mangoni@unina.it (A.M.)

2 Department of Clinical and Experimental Medicine, University of Perugia, Via Gerardo Dottori 1, S. Andrea delle Fratte, 06132 Perugia, Italy; E-Mails: barbara.renga@unipg.it (B.R.); fiorucci@unipg.it (S.F.)

* Author to whom correspondence should be addressed; E-Mail: valeria.costantino@unina.it; Tel.: +39-081-678-504; Fax: +39-081-678-552.

Received: 20 April 2012; in revised form: 17 May 2012 / Accepted: 1 June 2012 /

Published: 14 June 2012

\begin{abstract}
Chalinulasterol (1) a new chlorinated sterol disulfate was isolated from the Caribbean sponge Chalinula molitba. Its structure was elucidated using mass spectrometry and NMR experiments. The possible role of chalinulasterol as modulator of the PXR nuclear receptor was investigated but, in spite of the close structural relationship with the PXR agonist solomonsterol A (2), it showed no activity. The structural requirements for the PXR nuclear receptor activity were discussed.
\end{abstract}

Keywords: sterol sulfate; chlorine-containing steroid; Chalinula molitba; structure elucidation; PXR modulator

\section{Introduction}

Sulfated sterols are a well-known class of secondary metabolites, often found in sponges and echinoderms [1,2], that are emerging as a new potential class of lead compounds in the research for new drugs. A recent paper [3] reports on the isolation from the sponge Theonella swinhoei of 
solomonsterols A (2) and B (3), tri-sulfated sterols having the cholestan skeleton. They differ from each other in the length of the side chain, and are among the few examples of truncated steroid derivatives isolated from marine sources. Both compounds have shown an important pharmacological activity, in that they are agonists of the PXR nuclear receptor [4]. PXR receptor is a transcription factor which is able to bind to a wide spectrum of structurally distinct endobiotic substrates and xenobiotic compounds, and is involved in innate immunity, xenobiotic metabolism, and detoxification [5,6]. PXR is proving to be an attractive target for small molecule drug discovery. In recent years, potential applications for exogenous PXR ligands have emerged in the treatment of important pathologies such as cancer [7] and inflammatory diseases [8].

As part of our research program focused on the search for new anti-inflammatory and anti-cancer lead compounds from marine sponges $[9,10]$, we analyzed the chemical composition of the Caribbean sponge Chalinula molitba (de Laubenfels, 1949), a light purple sponge that habits the mangroves of Little San Salvador (Bahamas Islands). This study led to isolation and structural identification of chalinulasterol (1) a new chlorinated sterol disulfate (Figure 1). Compound $\mathbf{1}$ has a close structural relationship with $\mathbf{2}$, differing from the latter compound in having a chlorine atom instead of a sulfate function at position $\mathrm{C}-24$ of the side chain. This relationship prompted us to investigate the possible role of 1 as modulator of the PXR receptors.

Figure 1. Structures of chalinulasterol (1) and of solomonsterol A (2) and B (3).

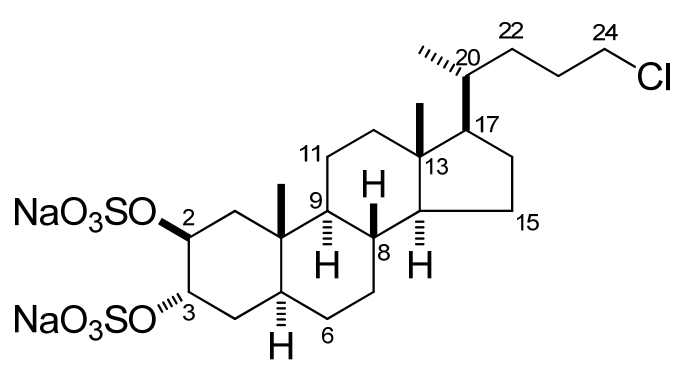

1

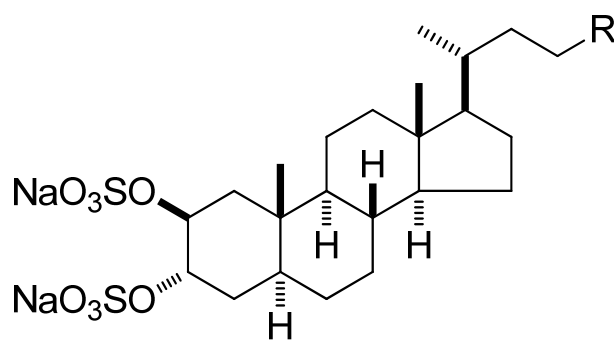

$2 \mathrm{R}=\mathrm{CH}_{2} \mathrm{OSO}_{3} \mathrm{Na}$

$3 \mathrm{R}=\mathrm{OSO}_{3} \mathrm{Na}$

\section{Results and Discussion}

The positive-ion high-resolution ESI mass spectrum of $\mathbf{1}$ displayed a $[\mathrm{M}+\mathrm{Na}]^{+}$pseudomolecular ion peak at $\mathrm{m} / \mathrm{z}$ 623.1447, in accordance with the formula $\mathrm{C}_{24} \mathrm{H}_{39} \mathrm{ClS}_{2} \mathrm{O}_{8} \mathrm{Na}_{3}{ }^{+}$for this ion (calcd. 623.1462). The intensity of the $(\mathrm{M}+2)$ isotopic peak in the MS spectrum $(45 \%$, calcd. $46.5 \%)$ and the peak at $m / z 587.1675\left([\mathrm{M}-\mathrm{HCl}+\mathrm{Na}]^{+}\right)$in the HRMS/MS spectrum confirmed the presence of a chlorine atom in the molecule. The MS/MS fragmentation pattern of 1 also revealed the presence of two sulfate groups from the peaks at $m / z 503.1946\left[\mathrm{M}-\mathrm{NaHSO}_{4}+\mathrm{Na}\right]^{+}, 262.8870\left[2 \mathrm{NaHSO}_{4}+\mathrm{Na}\right]^{+}$, and $244.8765\left[\mathrm{Na}_{2} \mathrm{~S}_{2} \mathrm{O}_{7}+\mathrm{Na}\right]^{+}$. The molecular formula was confirmed by the pseudomolecular ion peak at $\mathrm{m} / z 577.1669$ observed in the negative-ion ESI mass spectrum, accounting for $\mathrm{C}_{24} \mathrm{H}_{39} \mathrm{ClS}_{2} \mathrm{O}_{8} \mathrm{Na}^{-}$ (calcd. 577.1678).

Inspection of the ${ }^{1} \mathrm{H}$ NMR spectrum of compound 1 showed two methyl singlets at $\delta 0.69\left(\mathrm{H}_{3}-18\right)$ and $\delta 1.01\left(\mathrm{H}_{3}-19\right)$ and one methyl doublet at $\delta 0.95\left(\mathrm{H}_{3}-21\right)$ suggesting its steroidal nature. The steroidal backbone could be assembled through the interpretation of COSY, TOCSY, HSQC and 
HMBC 2D NMR experiments (Figure 2 and Table 1). Analysis of the COSY and TOCSY spectra allowed the sequential assignment of all the protons of the tetracyclic system. The sulfate groups were located at position C-2 and C-3 because of the low-field resonances of H-2 and H-3 ( $\delta 4.72$ and 4.69) and of the respective carbon atoms $\mathrm{C}-2$ and $\mathrm{C}-3$ ( $\delta 76.5$ and 76.3). The HMBC correlation peaks of the methyl protons $\mathrm{H}_{3}-19$ with $\mathrm{C}-1, \mathrm{C}-5$, C-9, and $\mathrm{C}-10$ and of $\mathrm{H}_{3}-18$ with $\mathrm{C}-12$, C-13, C-14, and C-17 located the $\mathrm{A} / \mathrm{B}$ and $\mathrm{C} / \mathrm{D}$ ring junctions and completed the planar structure determination of the steroid ring system.

Figure 2. (a) Selected COSY and HMBC correlations of 1, represented as bold bonds and arrows, respectively. (b) Selected ROESY correlations detected for $\mathbf{1}$.

(a)

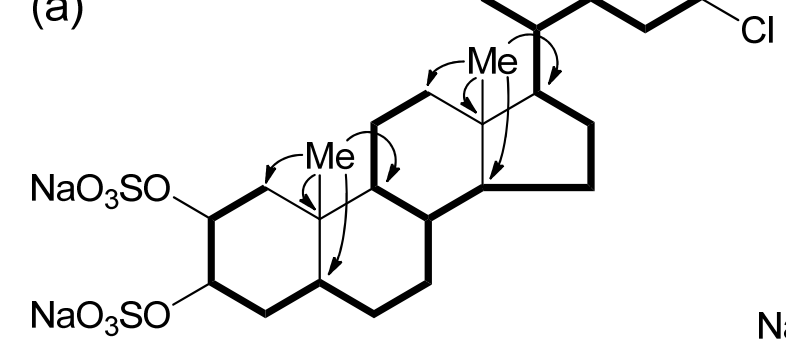

(b)

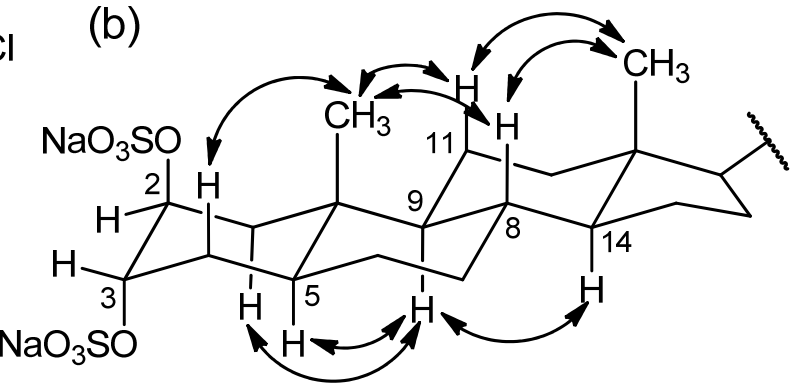

Table 1. ${ }^{1} \mathrm{H}(700 \mathrm{MHz})$ and ${ }^{13} \mathrm{C}(175 \mathrm{MHz}) \mathrm{NMR}$ data of chalinulasterol (1) in $\mathrm{CD}_{3} \mathrm{OD}$.

\begin{tabular}{|c|c|c|c|c|c|c|c|}
\hline Pos. & & $\delta_{\mathrm{H}}\left[\right.$ mult. $\left.{ }^{\mathrm{a}}, J(\mathrm{~Hz})\right]$ & $\delta_{\mathrm{C}}[$ mult.] & Pos. & & $\delta_{\mathrm{H}}\left[\right.$ mult. $\left.{ }^{\mathrm{a}}, J(\mathrm{~Hz})\right]$ & $\delta_{\mathrm{C}}$ [mult.] \\
\hline \multirow[t]{2}{*}{1} & $\alpha / \mathrm{ax}$ & $1.38(\mathrm{dd}, 14.6,3.5)$ & $39.1\left(\mathrm{CH}_{2}\right)$ & 13 & & - & $43.8(\mathrm{C})$ \\
\hline & $\beta /$ eq & $2.12(\mathrm{dd}, 14.6,2.1)$ & & 14 & & $1.05(\mathrm{~m})$ & $57.8(\mathrm{CH})$ \\
\hline 2 & & $4.72(\mathrm{q}, 2.7)$ & $76.5(\mathrm{CH})$ & 15 & $\alpha$ & $1.59(\mathrm{~m})$ & $25.2\left(\mathrm{CH}_{2}\right)$ \\
\hline 3 & & $4.69(\mathrm{q}, 2.7)$ & $76.3(\mathrm{CH})$ & & $\beta$ & $1.08(\mathrm{~m})$ & \\
\hline \multirow[t]{2}{*}{4} & $\alpha /$ eq & $1.66(\mathrm{dt}, 14.6,2.7)$ & $30.4\left(\mathrm{CH}_{2}\right)$ & 16 & $\alpha$ & $1.86(\mathrm{ddd}, 14.6,9.4,3.9)$ & $29.3\left(\mathrm{CH}_{2}\right)$ \\
\hline & $\beta / a x$ & $1.79(\mathrm{ddd}, 14.6,12.6,2.7)$ & & & $\beta$ & $1.28^{\mathrm{a}}$ & \\
\hline 5 & & $1.62(\mathrm{tt}, 12.6,2.7)$ & $40.3(\mathrm{CH})$ & 17 & & $1.12(\mathrm{q}, 9.7)$ & $57.5(\mathrm{CH})$ \\
\hline \multirow[t]{2}{*}{6} & $\alpha /$ eq & 1.25 (br. d, 14.5) & $29.2\left(\mathrm{CH}_{2}\right)$ & 18 & & $0.69(\mathrm{~s})$ & $12.8\left(\mathrm{CH}_{3}\right)$ \\
\hline & $\beta / \mathrm{ax}$ & $1.29(\mathrm{qd}, 12.7,3.5)$ & & 19 & & $1.01(\mathrm{~s})$ & $14.2\left(\mathrm{CH}_{3}\right)$ \\
\hline \multirow[t]{2}{*}{7} & $\alpha / \mathrm{ax}$ & $0.95(\mathrm{qd}, 12.6,4.6)$ & $33.3\left(\mathrm{CH}_{2}\right)$ & 20 & & $1.44(\mathrm{~m})$ & $36.6(\mathrm{CH})$ \\
\hline & $\beta / \mathrm{eq}$ & $1.68(\mathrm{dq}, 13.0 .3 .3)$ & & 21 & & $0.95(\mathrm{~d}, 6.5)$ & $19.2\left(\mathrm{CH}_{3}\right)$ \\
\hline 8 & & $1.41(\mathrm{qd}, 11.2,3.5)$ & $36.5(\mathrm{CH})$ & 22 & $\mathrm{a}$ & $1.56(\mathrm{dddd}, 13.4,10.6,5.6,2.9)$ & $34.4\left(\mathrm{CH}_{2}\right)$ \\
\hline 9 & & $0.72(\mathrm{ddd}, 13.2,10.5,3.8)$ & $56.7(\mathrm{CH})$ & & $\mathrm{b}$ & $1.15(\mathrm{dddd}, 13.4,10.6,8.8,4.3)$ & \\
\hline 10 & & - & $36.4(\mathrm{C})$ & 23 & $\mathrm{a}$ & $1.81(\mathrm{ddtd}, 13.9,11.2,7.1,4.5)$ & $30.6\left(\mathrm{CH}_{2}\right)$ \\
\hline \multirow[t]{2}{*}{11} & $\alpha /$ eq & $1.53(\mathrm{dq}, 14.1,3.5)$ & $22.1\left(\mathrm{CH}_{2}\right)$ & & $\mathrm{b}$ & $1.65(\mathrm{ddq}, 13.9,10.9,5.7)$ & \\
\hline & $\beta / \mathrm{ax}$ & $1.33(\mathrm{qd}, 13.2,3.7)$ & & 24 & $\mathrm{a}$ & $3.53(\mathrm{dt}, 10.7,6.5)$ & $46.4\left(\mathrm{CH}_{2}\right)$ \\
\hline \multirow[t]{2}{*}{12} & $\alpha / \mathrm{ax}$ & $1.14(\mathrm{td}, 12.6,3.8)$ & $41.4\left(\mathrm{CH}_{2}\right)$ & & $\mathrm{b}$ & $3.51(\mathrm{ddd}, 10.7,7.1,6.4)$ & \\
\hline & $\beta / \mathrm{eq}$ & $1.99(\mathrm{dt}, 12.2,3.5)$ & & & & & \\
\hline
\end{tabular}

${ }^{a}$ Multiplicity and coupling constants of overlapping signals were determined using sections of the zTOCSY spectrum [11]; $\mathrm{dt}=$ doublet of triplets, $\mathrm{td}=$ triplet of doublets, $\mathrm{dq}=$ doublet of quartets, etc.

Information on the side chain was also provided by analysis of 2D NMR data. The COSY correlation between $\mathrm{H}-17$ and the multiplet at $\delta 1.44$ identified $\mathrm{H}-20$; the latter was coupled with the methyl $\mathrm{H}_{3}-21$ and the protons at $\delta 1.15$ and $1.56(\mathrm{H}-22 \mathrm{a}$ and $\mathrm{H}-22 \mathrm{~b})$, in turn coupled with the 
methylene protons at $\delta 1.65$ and $1.81(\mathrm{H}-23 \mathrm{a}$ and $\mathrm{H}-23 \mathrm{~b})$. The coupling of $\mathrm{H}-23 \mathrm{a}$ and $\mathrm{H}-23 \mathrm{~b}$ and the two protons at $\delta 3.51$ and $3.53(\mathrm{H}-24 \mathrm{a}$, and $\mathrm{H}-24 \mathrm{~b})$ could be also evidenced from the COSY spectrum. The linkage to this latter methylene group of the chlorine atom required from the molecular formula was shown by its ${ }^{1} \mathrm{H}(\delta 3.51$ and 3.53$)$ and ${ }^{13} \mathrm{C}(\delta 46.4)$ chemical shifts.

Analysis of the ROESY spectrum, supported by coupling constant analysis, defined the A/B, B/C and $\mathrm{C} / \mathrm{D}$ trans ring junctions of a $5-\alpha$-cholane skeleton. The axial orientation of H-5, H-8, H-9, and H-14 was apparent from their respective coupling constants (Table 1), that of the angular methyl groups from the ROESY correlations of both $\mathrm{H}_{3}-18$ and $\mathrm{H}_{3}-19$ with $\mathrm{H}-8$ and the axial $\mathrm{H}-11 \beta$. On this skeleton, the small coupling constants showed by $\mathrm{H}-2$ and $\mathrm{H}-3$ illustrated their equatorial orientation, and therefore the diaxial (i.e., 2 $\beta, 3 \alpha$ ) orientation of the two sulfate groups. According to this information, the structure of chalinulasterol (1) was established as sodium 24 -chloro-5 $\alpha$-cholane-2 $\beta, 3 \alpha$-diyl 2,3-disulfate.

Figure 3. $(\mathbf{A}, \mathbf{B})$ Luciferase reporter assay. HepG2 cells, a hepatocarcinoma cell line, were transiently transfected with pSG5-PXR, pSG5-RXR, pCMV-ßgalactosidase and $\mathrm{p}(\mathrm{CYP3A} 4)-\mathrm{TK}-\mathrm{Luc}$ vectors and then stimulated with (A) $10 \mu \mathrm{M}$ rifaximin, solomonsterol A (2) or chalinulasterol (1) for $18 \mathrm{~h}$, or (B) $10 \mu \mathrm{M}$ rifaximin alone or in combination with $50 \mu \mathrm{M}$ of compounds 1 . Relative Luciferase Units were normalized with $\beta$-galactosidase Units (RLU/ßgal). NT, not treated. ${ }^{*} P<0.05$ versus NT cells. Data are mean $\pm \mathrm{SE}$ of three experiments. (C) Real-Time PCR of Cyp3A4. HepG2 cells were stimulated with $10 \mu \mathrm{M}$ rifaximin, 2 or $\mathbf{1}$ for $18 \mathrm{~h}$. Total RNA was extracted and the relative mRNA levels of PXR target gene Cyp3A4, was measured. Values were normalized relative to GAPDH mRNA and are expressed relative to those of untreated mice, which are arbitrarily set to 1 . Analysis was carried out in triplicate and the experiment was repeated twice. NT, not treated. $* P<0.05$ versus $\mathrm{NT}$ cells.

A.

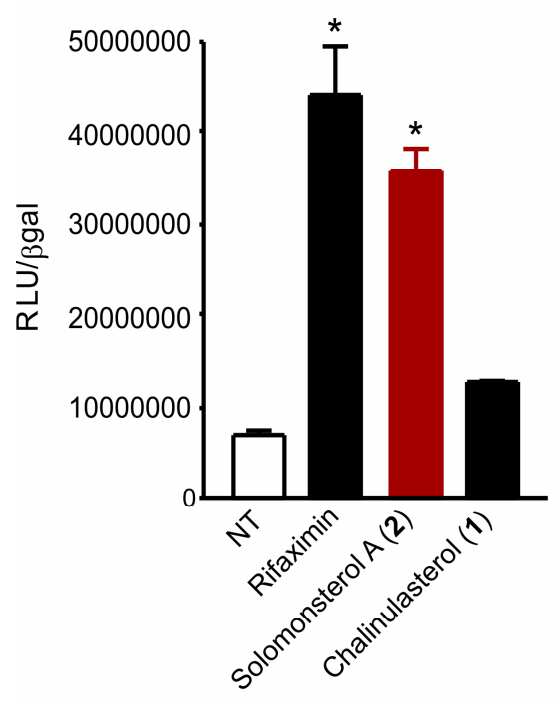

B.

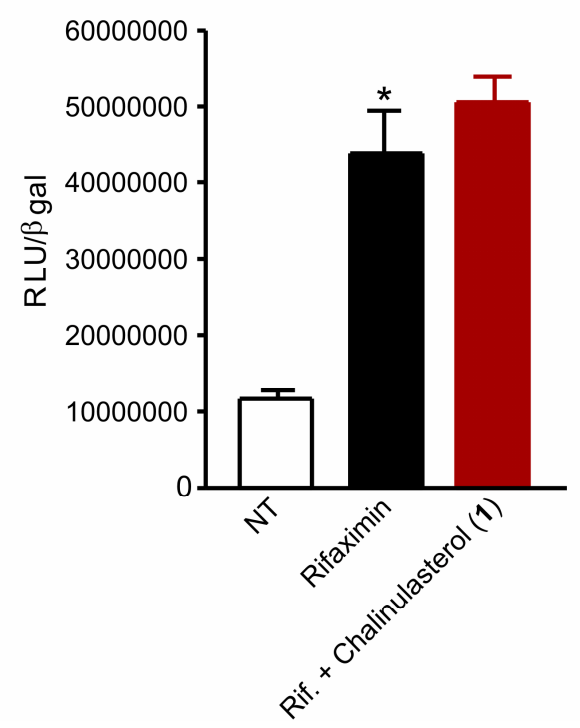

C.

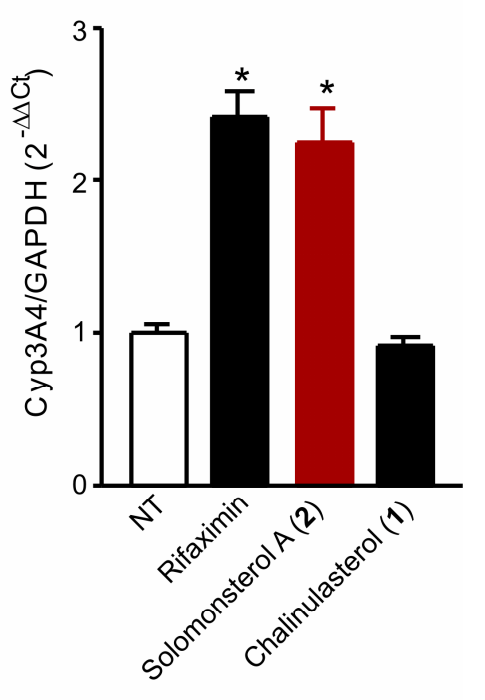

Considering the structural similarity with the PXR agonist solomonsterol A (2), we have investigated a possible role of chalinulasterol (1) in regulating the pregnane-X receptor activity and carried out a transactivation assay on HepG2 cells, a human hepatocarcinoma cell line as described in 
the Experimental Part. As shown in Figure 3A, despite the structural similarity with 2, compound $\mathbf{1}$ failed in transactivating PXR. We have also investigated the possibility that $\mathbf{1}$ could act as potential PXR antagonist. As shown in Figure 3B, 1 failed to reverse the induction of luciferase caused by rifaximin, indicating that it was not a PXR antagonist. Similar results have been obtained by analyzing the effect exerted by $\mathbf{1}$ in terms of regulation of PXR mediated induction of Cyp3A4 gene. Indeed, 1 also failed to induce Cyp3A4. Although negative, these results have an important implication in terms of structure-activity relationship, because they suggest that the sulfate group present at position C-24 of compound 2 is essential in the ligand-receptor binding. This can be rationalized by the binding model of 2 to the PXR receptor proposed in [3], in which a clear interaction of the 24-sulfate with the positively charged Lys 210 is observed, and further supports this model.

Although halogen-containing secondary metabolites are well-known and abundant in nature, particularly in marine organisms, only a few natural chlorinated steroids have been reported so far $[12,13]$, and there is only one example in the literature of a sulfated and chlorinated steroid [14].

\section{Experimental Section}

\subsection{General Experimental Procedures}

High-resolution ESI-MS spectra were performed on a Thermo LTQ Orbitrap XL mass spectrometer. The spectra were recorded by infusion into the ESI source using $\mathrm{MeOH}$ as the solvent. Optical rotations were measured at $589 \mathrm{~nm}$ on a Jasco P-2000 polarimeter using a 10-cm microcell. CD spectra were recorded on a Jasco J-710 spectrophotometer using a 1-cm cell. NMR spectra were determined on Varian Unity Inova spectrometers at 700 and $500 \mathrm{MHz}$; chemical shifts were referenced to the residual solvent signal $\left(\mathrm{CD}_{3} \mathrm{OD}: \delta_{\mathrm{H}} 3.31, \delta_{\mathrm{C}} 49.00\right)$. For an accurate measurement of the coupling constants, the one-dimensional ${ }^{1} \mathrm{H}$ NMR spectra were transformed at $64 \mathrm{~K}$ points (digital resolution: $0.09 \mathrm{~Hz}$ ). Through-space ${ }^{1} \mathrm{H}$ connectivities were evidenced using a ROESY experiment with a mixing time of $450 \mathrm{~ms}$. The HSQC spectra were optimized for ${ }^{1} J_{\mathrm{CH}}=142 \mathrm{~Hz}$, and the $\mathrm{HMBC}$ experiments for ${ }^{2,3} J_{\mathrm{CH}}=8.3 \mathrm{~Hz}$. High performance liquid chromatography (HPLC) separations were achieved on a Varian Prostar 210 apparatus equipped with a Varian 350 refractive index detector.

\subsection{Collection, Extraction, and Isolation}

Specimens of Chalinula molitba were collected in the mangroves of Little San Salvador (Bahamas Islands) during the 2010 Pawlik expedition. The samples were frozen immediately after collection and stored at $-20{ }^{\circ} \mathrm{C}$ until extraction. The sponge ( $424 \mathrm{~g}$ of dry weight after extraction) was homogenized and extracted with $\mathrm{MeOH}(5 \times 4 \mathrm{~L})$ and then with $\mathrm{CHCl}_{3}(2 \times 4 \mathrm{~L})$. The $\mathrm{MeOH}$ extracts were partitioned between $\mathrm{H}_{2} \mathrm{O}$ and $n-\mathrm{BuOH}$; the $\mathrm{BuOH}$ layer was combined with the $\mathrm{CHCl}_{3}$ extract and concentrated in vacuo.

The organic extract $(10,70 \mathrm{~g})$ was chromatographed on a column packed with RP-18 silica gel. A fraction eluted with $\mathrm{MeOH} / \mathrm{H}_{2} \mathrm{O}(8: 2,150 \mathrm{mg})$ was subjected to HPLC separation on a preparative RP-18 column $\left[\mathrm{MeOH} / \mathrm{H}_{2} \mathrm{O}(6: 4)\right.$, Ascentis ${ }^{\circledR} \mathrm{C} 18-25 \mathrm{~cm} \times 10 \mathrm{~mm}, 5 \mu \mathrm{m}-$ SUPELCO $\left.^{\circledR}\right]$, thus affording a fraction $(1.4 \mathrm{mg})$ mainly composed of $\mathbf{1}$. 
Final purification was achieved by HPLC on an analytical RP-18 column (Ascentis ${ }^{\circledR} \mathrm{C} 18-25 \mathrm{~cm} \times$ $4.6 \mathrm{~mm}, 5 \mu \mathrm{m}$-SUPELCO ${ }^{\circledR}$ ), using $\mathrm{MeOH} / \mathrm{H}_{2} \mathrm{O}(6: 4)$ as eluent, which gave $1 \mathrm{mg}$ of pure compound 1.

\subsection{Chalinulasterol (1)}

Colorless amorphous solid, $[\alpha]_{\mathrm{D}}^{25}+11.4$ (c $0.1, \mathrm{MeOH}$ ); HRESIMS (positive ion mode, $\mathrm{MeOH}$ ) $m / z 623.1447\left([\mathrm{M}+\mathrm{Na}]^{+}\right.$, calcd. for $\mathrm{C}_{24} \mathrm{H}_{39} \mathrm{ClS}_{2} \mathrm{O}_{8} \mathrm{Na}_{3}{ }^{+}$623.1462); MS isotope pattern: $\mathrm{M}(100 \%)$, $\mathrm{M}+1(27.5 \%$, calcd. $27.8 \%), \mathrm{M}+2$ (45.5\%, calcd. 46.4\%), $\mathrm{M}+3(11.5 \%$, calcd. $12.2 \%$, $), \mathrm{M}+4$ (4.9\%, calcd. 5.4\%); ${ }^{1} \mathrm{H}$ and ${ }^{13} \mathrm{C}$ NMR: Table 1.

\subsection{Cell Culture}

HepG2 cells were maintained at $37{ }^{\circ} \mathrm{C}$ in E-MEM containing $10 \%$ fetal bovine serum (FBS), $1 \% \mathrm{~L}$-glutamine and $1 \%$ penicillin/streptomycin. HepG2 cells were stimulated $18 \mathrm{~h}$ with $10 \mu \mathrm{M}$ rifaximin, $\mathbf{1}$ and compound 2-10 and relative mRNA levels of CYP3A4 were analyzed by Real-Time PCR.

\subsection{Transactivation Experiments}

HepG2 cells were transfeted using Fugene HD transfection reagent (Roche). The plasmids used for luciferase assay were pSG5-PXR, pSG5-RXR, pCMV-ßgalactosidase and the reporter vector $\mathrm{p}$ (CYP3A4)-TK-Luc. $48 \mathrm{~h}$ post-transfection cells were stimulated $18 \mathrm{~h}$ with $10 \mu \mathrm{M}$ rifaximin, Solomonsterol A, compound 1 or with the combination of $10 \mu \mathrm{M}$ rifaximin plus $50 \mu \mathrm{M}$ compound $\mathbf{1}$. Cells were lysed in $100 \mu \mathrm{L}$ diluted reporter lysis buffer (Promega). $20 \mu \mathrm{L}$ of cellular lysates were read using the Luciferase Substrate (Promega). Luminescence was measured using the Glomax 10/10 luminometer (Promega). Luciferase activities were normalized for transfection efficiencies by dividing the relative light units by $\beta$-galactosidase activity expressed from cotransfected pCMV- $\beta$ gal.

\subsection{Real-Time PCR}

Total RNA was extracted using the TRIzol reagent (Invitrogen), purified of the genomic DNA by DNAase I treatment (Invitrogen) and random reverse-transcribed with Superscript II (Invitrogen). $50 \mathrm{ng}$ template was amplified using the following reagents: $0.2 \mu \mathrm{M}$ of each primer and $12.5 \mu \mathrm{L}$ of $2 \times$ SYBR Green qPCR master mix (Invitrogen). All reactions were performed in triplicate and the thermal cycling conditions were: $2 \mathrm{~min}$ at $95^{\circ} \mathrm{C}$, followed by 40 cycles of $95{ }^{\circ} \mathrm{C}$ for $20 \mathrm{~s}, 55^{\circ} \mathrm{C}$ for $20 \mathrm{~s}$ and $72{ }^{\circ} \mathrm{C}$ for $30 \mathrm{~s}$ in iCycler iQ instrument (Bio-Rad). The relative mRNA expression was calculated and expressed as $2^{-(\Delta \Delta \mathrm{Ct})}$. Primers used for qRT-PCR were: hGAPDH: GAAGGTGAA GGTCGGAGT and CATGGGTGGAATCATATTGGAA; hCYP3A4: CAAGACCCCTTTGTGG AAAA and CGAGGCGACTTTCTTTCATC.

\subsection{Statistical Analysis}

All values are expressed as means \pm standard error (SE) of $n$ observations/group. Comparisons of 2 groups were made with a one-wayANOVA with post hoc Tukey's test. Differences were considered statistically significant at values of $P<0.05$. 


\section{Conclusions}

The structure of chalinulasterol (1), a new chlorinated sterol disulfate isolated from the Caribbean sponge Chalinula molitba, was elucidated using mass spectrometry and NMR experiments. Chalinulasterol is only the second example of a sulfated and chlorinated natural steroid. The possible role of chalinulasterol as modulator of the PXR nuclear receptor was investigated, but, in spite of the close similarity with the strongly active solomonsterols $\mathbf{2}$ and $\mathbf{3}$, resulted to be inactive. This suggests that the sulfate group present at the side chain of solomonosterols is essential in the ligand-receptor binding.

\section{Acknowledgments}

The research leading to these results has received funding from the European Union's Seventh Framework Programme FP7/2007-2013 under grant agreement No. 229893 (NatPharma) and from MIUR (PRIN 2009) "Sostanze ad attività antitumorale: isolamento da fonti marine, sintesi di analoghi e ulteriore sviluppo della chemoteca LIBIOMOL", Rome, Italy. Warm thanks are due to Joe Pawlik (University of North Carolina at Wilmington) for collecting the sponge, and Sven Zea (Universidad Nacional de Colombia) for identifying it. Mass and NMR spectra were recorded at CSIAS, Università di Napoli "Federico II". The assistance of the staff is gratefully acknowledged.

\section{References}

1. Sperry, S.; Crews, P. Haliclostanone sulfate and halistanol sulfate from an Indo-Pacific Haliclona sponge. J. Nat. Prod. 1997, 60, 29-32.

2. Aiello, A.; Menna, M.; Fattorusso, E. Steroids from sponges: Recent reports. Steroids 1999, 64, 687-714.

3. Festa, C.; De Marino, S.; D’Auria, M.V.; Bifulco, G.; Renga, B.; Fiorucci, S.; Petek, S.; Zampella, A. Solomonsterols A and B from Theonella swinhoei. The first example of C-24 and C-23 sulfated sterols from a marine source endowed with a PXR agonistic activity. J. Med. Chem. 2011, 54, 401-405.

4. Sepe, V.; Ummarino, R.; D’Auria M.V.; Mencarelli, A.; D’Amore, C.; Renga, B.; Zampella, A.; Fiorucci, S. Total synthesis and pharmacological characterization of solomonsterol A, a potent marine pregnane-X-receptor agonist endowed with anti-inflammatory activity. J. Med. Chem. 2011, 54, 4590-4599.

5. Rock, K.L.; Latz, E.; Ontiveros, F.; Kono, H. The sterile inflammatory response. Annu. Rev. Immunol. 2010, 28, 321-342.

6. Matic, M.; Mahnsa, A.; Tsoli, M.; Corradin, A.; Polly, P.; Robertson, G.R. Pregnane X Receptor: Promiscuous regulator of detoxification pathways. Int. J. Biochem. Cell Biol. 2007, 39, 478-483.

7. Chen, Y.; Tang, Y.; Guo, C.; Wang, J.; Boral, D.; Nie, D. Nuclear receptors in the multidrug resistance through the regulation of drug-metabolizing enzymes and drug transporters. Biochem. Pharmacol. 2012, 83, 1112-1126. 
8. Mencarelli, A.; Migliorati, M.; Barbanti, M.; Cipriani, S.; Palladino, G.; Distrutti, E.; Renga, B.; Fiorucci, S. Pregnane-X-receptor mediates the anti-inflammatory activities of rifaximin on detoxification pathways in intestinal epithelial cells. Biochem. Pharmacol. 2010, 80, 1700-1707.

9. Costantino, V.; Fattorusso, E.; Mangoni, A.; Perinu, C.; Cirino, G.; De Gruttola, L.; Roviezzo, F. Tedanol: A potent anti-inflammatory ent-pimarane diterpene from the Caribbean Sponge Tedania ignis. Bioorg. Med. Chem. 2009, 17, 7542-7547.

10. Lamoral-Theys, D.; Fattorusso, E.; Mangoni, A.; Perinu, C.; Kiss, R.; Costantino, V. Evaluation of the antiproliferative activity of diterpene isonitriles from the sponge Pseudoaxinella flava in apoptosis-sensitive and apoptosis-resistant cancer cell lines. J. Nat. Prod. 2011, 74, 2299-2303.

11. Mangoni, A. Strategies for structural assignment of marine matural products through advanced NMR-based techniques. In Handbook of Marine Natural Products; Fattorusso, E., Gerwick, W.H., Taglialatela-Scafati O., Eds.; Spinger: Heidelberg, Germany, 2012; Volume 1, Chapter 8, pp. 519-546.

12. Teruya, T.; Nakagawa, S.; Koyama, T.; Arimoto, H.; Kita, M.; Uemura, D. Nakiterpiosin and nakiterpiosinone, novel cytotoxic C-nor-D-homosteroids from the Okinawan sponge Terpios hoshinota. Tetrahedron 2004, 60, 6989-6993.

13. Fattorusso, E.; Taglialatela-Scafati, O.; Petrucci, F.; Bavestrello, G.; Calcinai, B.; Cerrano, C.; Di Meglio, P.; Ianaro, A. Polychlorinated androstanes from the burrowing sponge Cliona nigricans. Org. Lett. 2004, 6, 1633-1635.

14. Guzii, A.G.; Makarieva, T.N.; Denisenko, V.A.; Dmitrenok, P.S.; Burtseva, Y.V.; Krasokhin, V.B.; Stonik, V.A. Topsentiasterol sulfates with novel iodinated and chlorinated side chains from the marine sponge Topsentia sp. Tetrahedron Lett. 2008, 49, 7191-7193.

Samples Availability: Available from the authors.

(C) 2012 by the authors; licensee MDPI, Basel, Switzerland. This article is an open access article distributed under the terms and conditions of the Creative Commons Attribution license (http://creativecommons.org/licenses/by/3.0/). 